Захарова О., Кияновська $\Lambda$. Мистецтво як потужний засіь зовнішньої політики ...

УДК 327.81

DOI https://doi.org/10.24919/2308-4863/34-2-4

Оксана ЗАХАРОВА,

orcid.org/0000-0002-2143-7020

доктор історичних наук, професор,

Національна академія керівних кадрів культури і мистецтв

(Київ, Україна) irinamak67@ukr.net

Любов КИЯНОВСЬКА, orcid.org/0000-0002-0117-5078 доктор мистеитв, професор, завідувач кафедри історії музики Львівської начіональної музичної академії імені М. В. Лисенка (Львів, Україна)luba.kyjan@gmail.com

\title{
МИСТЕЦТВО ЯК ПОТУЖНИЙ ЗАСІБ ЗОВНІШНЬОЇ ПОЛІТИКИ (КУЛЬТУРНА СКЛАДОВА ЧАСТИНА ПРОГРАМ ЗАРУБІЖНИХ ВІЗИТІВ ДО СРСР ІЗ ВІДВІДУВАННЯМ УКРАЇНИ (ПОЧАТОК 20-Х - ПОЧАТОК 80-Х РР. ХХ СТ.)
}

\footnotetext{
Актуальність дослідження визначається як недостатньою вивченістю дипломатичного протоколу України та Росії в зазначений період, так і тим, щчо знання закономірностей функціонування останнього розширюють наші уявлення не тільки про зовнішню політику і міжнародні відносини, а й про особливості розвитку культури в Україні та Росії після жовтневого перевороту 1917 р. 3 урахуванням відсутності у вітчизняній історіографіі спеціального дослідження, присвяченого иіий проблемі, автор поставив мету - на основі аналізу й узагальнення нових фактів, залучивщи вперше в науковий обіг архівні матеріали, вивчити культурну складову частину програм візитів в Украӥну та Росію глав зарубіжних держав, урядів, іноземних відомств, політичних, військових $i$ громадських діячів.

Новизна дослідження полягає в комплексному підході до вивчення зарубіжних візитів, культурна складова частина програм яких донедавна не піддавалася науковому аналізу.

Хронологічні рамки дослідження охоплюють період із початку 20-х до початку 80-х рр. XX cm.

Нижня хронологічна межа зумовлена тим, що на початку 20-х рр. відбувається процес розширення міжнародних контактів СРСР, а також тим, щцо саме циим часом датуються перші документи протокольної частини Наркомату закордонних справ (НКЗС), які містять інформаџію про візити делегаџї в Росію та Украйну, виявлені в Архіві зовнішньої політики Російської Федерації (Фонд 057).

Кінцева хронологічна межа - початок 80-х рр. ХХ cm. Це завершення певного періоду в історії дипломатії України та Росії, коли сталася раціоналізація протокольних норм, розроблених $і$ апробованих на практиці у попередні роки.

Проаналізовано зміст програм візитів в Украӥну та Росію Аманулли-хана, У. Черчіля, Ш. де Голля, Й. Б. Тіто, Мао Цзедуна, Індіри Ганді, королеви Бельгї Єлизавети, П. Трюдо та інших державних і політичних діячів.

Виявлено, що у програмах зарубіжних візитів особливе місие відводилося так званій «культурній складовій частині», тобто відвідуванню гостями театрів, концертів, музеїв.

Протягом століть дипломатичний протокол зазнав значних змін, незмінним залишалося одне - дипломатичні иеремоніали, важливою частиною яких була культурна складова частина, насамперед музичне мистецтво. Саме вони зобов'язані підтримувати ілюзію могутності держави. Вже на початку 20-х рр. стає очевидно, щео неможливо вибудовувати партнерські відносини із зарубіжними краӥнами без дотримання загальноприйнятих європейських норм, традицій і умовностей у міжнародному спілкуванні. Нині триває процес демократизації протокольних норм. Поряд із ичим 3МI, висвітлюючи закордонні візити глав держав і урядів, уважно відстежують стиль і манери поведінки представників політичної еліти. Дипломатичний протокол, будучи частиною державної иеремоніальною культури, є ілюстрацією духовного, морального, політичного стану суспільства.

Багатонаціональна радянська культура сприяла створенню позитивного іміджу держави на світовій арені. Культурна дипломатія була головним фактором публічної дипломатії України та Росії в зазначений період.
}

Ключові слова: дипломатія, культура, протокол, закордонні візити, імідж держави. 
Oksana ZAKHAROVA, orcid.org/0000-0002-2143-7020

Doctor of Historical Sciences, Professor, National Academy of Culture and Arts Management (Kyiv,Ukraine)irinamak67@ukr.net

Lyubov KIYANOVSKAYA, orcid.org/0000-0002-0117-5078

Doctor of Arts, Professor,

Head of the Department of Music History Lviv National Music Academy named after Mykola Lysenko (Lviv,Ukraine)luba.kyjan@gmail.com

\section{ART AS A POWERFUL MEANS OF FOREIGN POLICY CULTURAL COMPONENT OF PROGRAMS OF FOREIGN VISITS TO THE USSR WITH VISITS TO UKRAINE (EARLY 20S - EARLY 80S OF XX CENTURY)}

The relevance of the study is determined both by insufficient study of the diplomatic protocol between Ukraine and Russia in this period, and the fact that knowledge of the laws of the latter expands our understanding not only of foreign policy and international relations, but also the peculiarities of cultural development in Ukraine and Russia after the October coup. 1917. Given the lack of special research in domestic historiography devoted to this problem, the author set a goal - based on the analysis and generalization of new facts, involving for the first time in the scientific circulation of archival materials, to study the cultural component of programs of visits to Ukraine and Russia. departments, politicians, military and public figures.

The novelty of the study lies in a comprehensive approach to the study of foreign visits, the cultural component of whose programs until recently was not subjected to scientific analysis.

The chronological framework of the study covers the period from the early 20s to the early 80s of the XX century.

The lower chronological limit is due to the fact that in the early 1920s the process of expanding international contacts with the USSR took place, as well as the fact that the first documents of the protocol part of the People's Commissariat for Foreign Affairs (NKVD) containing information about the delegation's visits to Russia and Ukraine found in the Archives of Foreign Policy of the Russian Federation (Fund 057).

The final chronological boundary is the beginning of the 1980s. This is the end of a certain period in the history of diplomacy of Ukraine and Russia, in which there was a rationalization of the protocol norms developed and tested in practice in previous years.

The content of the programs of visits to Ukraine and Russia by Amanulli-khan, W. Churchill, S. de Gaulle, I. B. Tito, Mao Zedong, Indira Gandhi, Queen Elizabeth of Belgium, P. Trudeau and other statesmen and politicians.

It was found that in the programs of foreign visits a special place was given to the so-called "cultural component", ie visiting theaters, concerts, museums.

Over the centuries, diplomatic protocol has undergone significant changes, one thing remained unchanged diplomatic ceremonies, an important part of which was the cultural component and, above all, the art of music. They are obliged to maintain the illusion of state power. Already in the early 1920s, it became clear that it was impossible to build partnerships with foreign countries without adhering to generally accepted European norms, traditions and conventions in international communication. The process of democratization of protocol norms is currently underway. At the same time, the media, covering the foreign visits of heads of state and government, closely monitor the style and manners of the political elite. Diplomatic protocol, being part of the state ceremonial culture, is an illustration of the spiritual, moral, political state of society: politics, prestige, the image of power.

Multinational Soviet culture contributed to the creation of a positive image of the state on the world stage. Cultural diplomacy was a major factor in the public diplomacy of Ukraine and Russia during this period.

Key words: diplomacy, culture, protocol, foreign visits, image of the state.

Постановка проблеми. Дипломатія як одна зі сфер прикладної політики є вельми складною і відповідальною галуззю людської діяльності.

У дипломатичних відносинах суверенних держав важливе місце посідають закордонні візити державних діячів. Візит - сукупність передусім протокольних заходів, характер яких залежить від виду візиту, котрий, у свою чергу, визначається політичною доцільністю.
Вибір предмета дослідження зумовлений тим, що вивчення дипломатичного протоколу України та Росії та його функціонування в зазначений період розширить наші уявлення не тільки про зовнішню політику та міжнародні відносини, а й про особливості розвитку культури в Україні та Росії після жовтневого перевороту 1917 р.

Аналіз досліджень. Історію протокольної практики візитів на вищому рівні розглянуто 
в окремих розділах монографій П. Ф. Лядова (Лядов, 2004: 64-89) і А. Ф. Борункова (Борунков, 2005: 150-163).

У монографії А. В. Голубєва і В. А. Невежина розглядається специфіка радянської культурної дипломатії 1920-х - середини 1940-х рр. (Голубєв, Невежин, 2016: 232).

3 урахуванням відсутності у вітчизняній історіографії спеціального дослідження, присвяченого цій проблемі, автори поставили мету - на основі аналізу й узагальнення нових фактів із залученням архівних матеріалів, які вперше вводяться в науковий обіг, провести вивчення культурної складової частини програм візитів в Україну і Росію глав зарубіжних держав, урядів, іноземних відомств, політичних, військових і громадських діячів.

Виклад основного матеріалу. Однією 3 важливих подій в історії радянсько-французьких відносин став візит у вересні 1922 р. до Москви відомого французького політичного діяча пана Epio. Iз цим візитом пов'язана перша виявлена нами в Архіві зовнішньої політики РФ згадка про включення до програми візиту відвідування Большого театру - балету «Лебедине озеро». Після спектаклю гості відбули на вечерю $з$ артистами, де пробули до 3 години ночі.

На завершення візиту (з 7 до 10 жовтня) Еріо зустрічався в Москві із Дзержинським, Луначарським, Троцьким. На балеті «Копелія» в ложу, де знаходився Еріо, передали телеграму від Пуанкаре, в якій останній поділяв його погляди (Пуанкаре, 1922: 19). У травні 1924 р. на парламентських виборах переміг лівий блок, у передвиборній кампанії якого був заклик до визнання СРСР. За 5 місяців сформований Еріо кабінет визнав радянську владу. У дипломатії немає дрібниць. Збалансована програма візиту 3 культурними заходами дозволяє досягти бажаного політичного результату.

У липні 1925 р. в Народному Комісаріаті закордонних справ почалася підготовка до візиту до Москви генерала Сю, котрий «їздить європейськими країнами й Америкою зі спеціальною місією Президента Китайської Республіки, як, так би мовити, надзвичайний посол», - повідомив Г. Чичерін у своєму посланні народному комісару військових і морських справ М. Фрунзе (10 липня) (Чичерін, 1925: 19). Чичерін звертає увагу Фрунзе на те, що в інших країнах генералу влаштували пишний прийом. Повноважний представник Китайської Республіки в Москві Лі Тья-Ло не раз ставив перед НКЗС питання про характер зустрічі та небажаність упущень через китайську чутливість до питань етикету. Органі- зація візиту китайського генерала проходила під гаслом «Більше пишності та сердечності, менше галасу і розголосу» (Чичерін, 1925: 3).

Проект зустрічі включав у себе: офіційні візити до членів радянського уряду; генералу Сю надаються ложі в Большому театрі-одна на балет і одна на оперу. Організовується огляд пам'яток Москви.

У 1920-х рр. закладалися основи радянських протокольних традицій. Наскільки активно відбувався розвиток протокольної служби НКЗС, свідчить підготовка до візиту до Москви кантонського міністра Ху Хан Міна у жовтні 1925 р., програма перебування котрого була складена не за хронологічним, а за тематичним принципом:

1. Бесіди із членами уряду (Калініним, Камєневим та ін.).

2. Комінтерн і РКП(б). Бесіди із Зіновьєвим, Сталіним, Молотовим, Радеком та ін.

3. Освіта. Бесіда 3 Луначарським. Відвідування дитбудинку, робітничого факультету, Центрального дому комуністичного виховання, лісової школи, Бібліотеки ім. Леніна.

4. Охорона здоров'я і фізкультура. Бесіда із Семашко. Відвідання Центрального інституту фізичної культури, Центрального дому материнства і дитинства.

5. Промисловість. Бесіди із Троцьким, Дзержинським, П'ятаковим. Відвідання заводів «Динамо», «АМО», «Каучук», Краснопрісненської бавовняної мануфактури, кондитерської фабрики «Красный Октябрь».

6. Торгівля.БесідиізКрасіним,Фрумкінимтаін.

7. Музеї. Відвідання Музею революції, Третьяковської галереї, Музею порцеляни, Музею красних мистецтв, Кремля.

8. Мавзолей В. І. Леніна.

9. Театри.

10.Клуби. Центральний комсомольський клуб, Центральний піонерський клуб.

11.Фінанси. Бесіди із Сокольниковим. Огляд золотого запасу Держбанку й Алмазного фонду СРCP.

12.Огляд показових закладів: Центрального дома селянина, Центрального інституту праці (Програма, 1925: 35-36).

У 20-х рр. протокольна частина НКЗС під керівництвом Д. Т. Флоринського становила колектив творчих особистостей, які не боялися експериментувати та розробляли норми протокольної практики, актуальні протягом десятиліть.

Спроба «примирити» європейський етикет i східні традиції, пристосувати їх до нових практичних радянських реалій відбулася у 1928 р. під час підготовки та проведення першого в історії СРСР 
візиту керівника іноземної держави - падишаха Афганістану Аманулли-хана. Вранці 4 травня падишах із родиною оглянув у Москві Збройну палату, а о 16 годині пив чай у Домі селянина.

Після обіду відбувся раут, на який запрошено весь дипкорпус (форма одягу - фрак). Начальники місій представляли падишаху і його дружині свій персонал. «Наших» дам королеві представляла Колонтай. Після невеликого концертного відділу джаз-бенд заграв фокстрот. Однак танцювати ніхто не наважився, i, щоби «врятувати» танцювальну частину прийому, Флоринському довелося відкрити бал з однією із присутніх дам. Близько півночі падишах покинув вечір, але деякі його міністри та більшість гостей залишилися до 2 години ночі.

Наступний день візиту не обійшовся без скандалу. Після відвідання аеродрому падишах із родиною і почетом відвідав іподром, де відбувся розіграш призу Незалежного Афганістану (падишах особисто передав дарунки наїзникові та конюху), а ввечері на урочистому спектаклі в ГАБТі відбулися певні протокольні «неприємності». Почалося все із протесту деяких іноземних кореспондентів, незадоволених своїми місцями в ложах другого ярусу. Їм довелося пояснювати, що ложі бельетажу призначені для дипкорпусу, i не можна посадити інкорів перед дипломатами. Однак поведінку інкорів неможливо порівняти iз поведінкою дружини Луначарського, яку ще до початку спектаклю і приїзду афганців Калініну довелося буквально виставити 3 центральної ложі. Та це не завадило їй знову «влізти» в ложу після першого антракту під приводом, що iï запросила афганська принцеса. Луначарському вказали на безцеремонну поведінку його жінки та попередили, що більше нікуди її не запрошуватимуть. У відповідь Луначарський заявив, що відмовляється від поїздки до Ленінграду. На жаль, цей ляпсус того вечора був не останнім. Падишах поставив протокольну службу у незручне становище, бо заявив, що бажає обідати в театрі, але там не було кухні, привезти із Софійської набережної обід і розігріти його у Великому Московському готелі було важко. Зрештою вирішили не скасовувати чайний прийом у першому антракті у Бетховенському залі із запрошеними головами місій, а обід сервувати у другому антракті. Останній інцидент того вечора стався із послом Франції Ж. Ербеттом, котрий після спектаклю «в різких виразах» заявив, що «йому ГПУ дихнути не дає і що його не пускають у центральні фойє» (там ще перебували падишах і вартові) (Перебування падишаха, 1928: 17).
Незважаючи на всі «проколи» того вечора, спектакль пройшов блискуче. Останні три дні перебування Аманулли-хана в Москві відбулися за тим самим планом, що й попередні, - відвідання військових і цивільних об'єктів, ввечері прийом чи зустріч у вузькому колі.

У 20-ті рр. економічні місії регулярно відвідували СРСР. У грудні 1927 р. двічі прибували делегації з Японії. Перша під керівництвом пана Кухари, другу очолював віконт Гото. Головна частина візиту пана Кухари пройшла у Ленінграді, куди той виїхав одразу після закінчення балету «Червоний мак» Р. Глієра у Большому театрі. В Ленінграді Кухара забажав відвідати Дитяче Село, де японська делегація дві години оглядала Катерининський i Олександрівський палаци. Після обіду члени делегації прибули в Маріїнський театр на «Есмеральду». Ленінградський балет сподобався гостям більше, ніж московський, на їхню думку, він «тонший», «більш одухотворений» (Програма візиту, 1927: 11).

Візити до СРСР торгово-промислових делегацій західноєвропейських країн продовжилися й у 1929 p.

Наприкінці березня 1929 р. до Москви прибула англійська промислова делегація. Програма перебування передбачала, що вранці та вдень гості відвідували радянські установи та промислові підприємства, а ввечері - московські театри.

У липні 1929 р. Протокольний відділ НКЗС займався підготовкою й організацією візиту до Москви та Харкова президента сенату Вільного міста Данцига (польського Гданська) пана Заама у супроводі членів данцигського уряду.

Культурна програма передбачала відвідання Третьяковської галереї у супроводі А. В. Луначарського. На вечорі грузинської музики під час антракту Єнукідзе пояснив гостям, що головна мета заходу - «підняття культурного рівня нацменшин». Ця заява справила на Заама і його супутників «чудове враження» (Візит, 1929: 17). До від’їзду до Харкова гості побували на Іподромі, в парку відпочинку і культури, зустрілися з ученими й артистами в будинку відпочинку «Вузьке». 12 липня делегація виїхала з Москви до Харкова. На вокзалі в Харкові із Заамом спробував поспілкуватися польський консул, але радянські службовці оточили Заама, не даючи консулу до нього «підібратися». На шляху делегації виставили почесні міліцейські пости, над готелем, де розмістили делегацію, підняли прапор Данцигу. Після сніданку в саду «Аркадія» відбулися візити до голови Раднаркому УРСР Чубаря, наркомторга Вейцера. Перед початком прийому, як і в Кремлі, Зааму від- 
дав рапорт начальник почесної варти, після чого Заам у супроводі ад'ютанта разом із супутниками зайшли у залу для прийомів, де їх зустріли члени Президіуму ВУ ЦВК. На прийомі підкреслювалися дружні відносини між УРСР і Данцигом, iз наркомторгом Вейцером детально обговорювався експорт з України в Данциг і через Данциг.

На зустрічі з українською пресою Заам підкреслив помічене ним «велике прагнення Українського уряду до розвитку української культури, що істотно важче для Данцига, якому доводиться відстоювати свою німецьку культуру». Ввечері делегація прийняла запрошення на прийом у німецького консула, запрошення польського консула «на чашку чаю» Заам відхилив (Візит, 1929: 17).

Із Харкова делегація відбула на Батьківщину. Урочистий прийом делегації з Данцига, увага радянських офіційних осіб особисто до Заама була викликана тим, що СРСР був зацікавлений у продовженні замовлень данцигським верфам при наданні Данцигом радянському уряду вигідних кредитів і якісного виконання замовлень. Невипадково одна з головних подій візиту - відвідання делегацією голови Радторгфлоту Зофа для перемовин про умови замовлень данцигським верфам. Відзначимо підкреслено дружні стосунки гостей iз німецькими дипломатами в Москві й у Харкові та небажання спілкуватися із представниками польської дипломатичної місії. Радянська сторона 3 допомогою норм офіційного протоколу підтримала поведінку Заама і членів делегації. У виборі між Польщею і Німеччиною СРСР був відверто на боці останньої.

5 серпня 1939 р. до Києва прибули депутати болгарського парламенту на чолі із заступником голови парламенту Марковим. Гості оглянули Київ, ввечері ж відвідали концерт джаз-оркестру Якова Скоморовського. «У Радянському Союзі ми вперше, - сказав перший секретар голови фінансової комісії Балканський, - і нас вражає велика творча робота радянського народу у всіх галузях: культурній, промисловій, сільськогосподарській та ін.» (Балканський, 1929: 8).

Уповноважений НКЗС при уряді УРСР К. Відякін дуже детально повідомляв Москву про хід візиту: навіть про те, що у 15-хвилинні антракти в театрі члени делегації «споживали прохолодні напої та морозиво» (Програма, 1939: 8). В антракті голова комісії іноземних справ Говедаров запитав Відякіна, чи буде підписана угода між Англією, Францією і СРСР «для захисту світу від агресії» (Програма, 1939: 8). Представник НКЗС завірив болгарських гостей, що радянський уряд робить все для підписання рівноправної угоди, і що при- їзд до СРСР англійських і французьких військових місій, імовірно, завершить підготовку до підписання угоди. На банкеті заступник голови болгарського парламенту підняв келих за подальше процвітання радянської культури та тісну співпрацю. Цей виступ Маркова зустріли бурхливою овацією й вигуками: «Хай живе тов. Сталін!», «За Радянську владу», «За працьовитий радянський народ!», «За дружбу з великим радянським народом!» (Програма, 1939: 10). Як зауважив Марков, «любов болгар до СРСР» проявилася після передачі радянським урядом 100 тисяч левів для Болгарії на допомогу постраждалим від повені ріки Росиці: «Народ любить СРСР», - підкреслив Марков (Програма, 1939: 10). На банкеті були присутні артисти джаз-оркестру Я. Скоморовського, В. Кораллі, К. Шульженко і конферансьє Г. Амурський. Гостям особливо сподобалася пісня «Тихий Дон» (Програма, 1939: 11). Із Києва болгарська делегація вирушила до Москви для відвідання сільськогосподарської виставки, потім до Ленінграду, а до Дня авіації (18 серпня) повернулася до Москви: Марков вважався добрим льотчиком. Проте у складі болгарської делегації не схотів їхати до СРСР відомий промисловець, котрий злякався «голоду в СРСР» (Програма, 1939: 14).

9 серпня на англійському кораблі у складі групи із 30 осіб прибули англійські та французькі військові представники.

21 серпня 1939 р. радник польського посольства повідомив телефоном НКЗС, що заступник міністра землеробства Кравульський виїжджає на сільськогосподарську виставку з Варшави 23 серпня.

Подальший перебіг Другої світової війни змусив радянську дипломатію робити достатньо різкі кульбіти і шукати нових союзників у смертельному протистоянні двох недавніх «друзів і однодумців».

Однією 3 головних подій дипломатичного життя Москви в жовтні 1944 р., яка знаменувала цей поворот, став приїзд до столиці СРСР прем'єр-міністра Великої Британії Вінстона Черчилля і міністра закордонних справ Ентоні Ідена. У центральній ложі на концерті в Большому театрі 14 жовтня 1944 р. перебували офіційні особи 3 обох сторін (Візит В. Черчилля, 1944: 26).

Програма концерту 14 жовтня 1944 р. складалася із двох відділів. У першому виконувався перший акт із балету А. Адана «Жизель» за участі провідних тогочасних артистів балету, відзначених Сталінськими преміями, Ольги Лепешинської, Суламіф і Асафа Мессерерів. У другому відділі виступили не менш відомі оперні співаки, теж сталінські лауреати Максим Михайлов, Наталя Шпіллер і Марія Максакова. Завершився кон- 
церт номерами, підготованими Краснознаменним ансамблем пісні й танцю СРСР (художній керівник і диригент - ще один сталінський лауреат Олександр Александров): кантата про Сталіна, російські народні пісні, українська народна пісня, російський танець, марш із опери Гуно «Фауст», «Темна ніч» Микити Богословського, танець донських козаків. У своїх спогадах В. Черчилль напише: «14 жовтня відбулася грандіозна вистава у Большому театрі - спершу балет, потім опера і на завершення програми розкішні танці та спів хору Червоної Армії. Сталін і я перебували у царській ложі, і глядачі влаштували нам захоплену овацію» (Черчилль, 1955: 228). Після спектаклю перемовини союзників продовжилися.

Роботу Протокольного відділу високо оцінила британська сторона. 18 жовтня 1944 р. від імені міністра закордонних справ Великої Британії надійшов лист, у якому британська делегація висловлювала вдячність «за прекрасну роботу протокольного відділу під час нашого перебування $<\ldots>$. Ми глибоко вдячні за вашу $<\ldots>$ постійну допомогу, ми забираємо із собою незабутнє враження, яке справила на нас російська доброта і гостинність, ми особливо вдячні за виставу в театрі опери і балету, влаштовану для нас» (Іден, 1944: 50).

20 жовтня 1944 р. В. Черчилль написав Сталіну: «Пам'ятна зустріч у Москві показала, що немає таких питань, які ми не можемо врегулювати, коли зустрічаємося для особистої та відвертої бесіди. Росіяни 3 їхньою широко відомою гостинністю перевершили самих себе у зв'язку з нашим приїздом. <..> Висловлюю глибоку вдячність вам і всім, хто турбувався про нас. Сподіваюся скоро знову зустрітися з вами» (Черчилль, 1955: 235).

6 червня 1944 р. почалася висадка військ Англії та США у Нормандії. 3 ними висадилися частини французьких патріотів на чолі із Шарлем де Голлем (де Голль, 1944: 28). 25 листопада 1944 р. В. М. Молотов затвердив «план зустрічі, перебування і проводів голови Тимчасового уряду Французької Республіки де Голля» (Де Голль, 1944: 28).

3 урахуванням побажань представника Тимчасового уряду Р. Гарро остаточно сформували програму, яка включала відвідування Большого театру, балету «Жизель» та опери «Іоланта». $\mathrm{У}$ центральній ложі поруч із Ш. де Голлем В. М. Молотов і М. М. Литвинов, над ложою вивішуються французькі та радянські прапори, перед початком вистави виконуються гімни Франції та СРСР, Концерт Краснознаменного ансамблю червоноармійської пісні й танцю в Большому театрі (перед початком виконуються гімни, ложа прикрашена прапорами) (Де Голль, 1944: 37).
Організація урядових прийомів - важлива складова частина діяльності Протокольного відділу. Слід було не лише підготувати списки запрошених, а й затвердити меню. Список запрошених на сніданок до Сталіна на честь де Голля 3 грудня 1944 р. очолювали з радянської сторони Й. В. Сталін, В. М. Молотов, А. І. Микоян, із французької - де Голль, Бідо, генерал Жуєн, Гарро та ін. (Де Голь, 1944: 48). На відміну від «сніданку Сталіна», на прийом у Молотова на честь генерала де Голля запросили не лише членів уряду, але й дипломатичний корпус, представників радянської творчої інтелігенції.

Запрошення на прийом - підтвердження високого соціального статусу (на відміну від членів уряду, вчені, музиканти, художники, письменники, скульптори, режисери й актори запрошувалися без дружин і чоловіків).

У списку окремо виділені прізвища академіків, артистів драми, Большого театру, кіно, письменників, художників, скульпторів.

Честі опинитися на Спиридонівській вулиці в домі 17 удостоїлися: академіки Карен Алабян, Микола Бруєвич, артисти драми Іван Москвін, Василь Качалов, Микола Хмельов, Клавдія Єланська, Михайло Царьов, Алла Тарасова, Марія Бабанова. Большой театр представляли Іван Козловський, Максим Михайлов, Валерія Барсова, Галина Уланова, Ольга Лепешинська, Олександр Мелік-Пашаєв (прізвище Мессерера викреслене), письменники М. Тихонов, I. Еренбург, С. Маршак, О. Толстой (олівцем вписані К. Сімонов, Л. Леонов); художники та скульптори А. Герасимов, С. Меркулов, М. Купріянов, Крилов; артисти кіно Л. Ладиніна, М. Крючков, І. Пир'єв (викреслені зі списку Г. Александров, Л. Орлова, М. Жаров, Л. Целіковська) (Де Голь, 1944: 53, 54).

На концерті Краснознаменного ансамблю червоноармійської пісні й танцю СРСР у Центральному домі Червоної армії були виконані: «Кантата про Сталіна» (музика Александрова), «Загибель «Варяга» (народна пісня), «Поема про Україну» (музика Александрова), «По вулиці Мостовій» (народна пісня), «Смуглянка» (музика Новикова), «Степ та й степ кругом» (народна пісня), «На сонячній полянці» (музика СоловйоваСєдого), «Червоноармійський танець» (музика Александрова і Куликова, постановка заслуженого артиста УРСР Вірського). Другий відділ почався маршем із опери Гуно «Фауст», потім прозвучали «Мрії» Шумана, «Славне море» (народна пісня), «Бандура» (українська пісня), «Вася-Васильок» (музика Новикова), вальс «У прифронтовому лісі» (музика Блантера), «Темна ніч» (музика Богослов- 
ського), завершився концерт танцем донських козаків (Де Голь, 1944: 69).

Президент Чехословацької Республіки Едвард Бенеш відвідав СРСР у березні 1945 р. Протокольний відділ почав підготовку до візиту в кінці лютого. До складу делегації входили 27 осіб: члени сім'ї Бенеша (дружина, племінниця), прем'єрміністр, міністр закордонних справ, міністр юстиції, міністр соціального забезпечення, члени Державної Ради і т. д.

Особливість візиту - спеціально складена програма для дружини президента 3 відвідуванням лікувальних, шкільних ідошкільних закладів(шпиталю, дитсадка, школи, пологового будинку і т. п.).

Відвідування 27 березня дружиною Бенеша балетної школи при Большому театрі викликало у гостей захват. На концерті учнів школи дружина президента особливо виділила ученицю старшого класу Ліду Дементьєву, пророкуючи ій велике майбутнє (Бенеш, 1945: 76).

На концерті 21 березня в Центральному домі Червоної армії виступали кращі мистецькі сили: хори П'ятницького і Свєшникова, Г. Уланова, М. Максакова, I. Козловський, М. Михайлов та ін. 24 березня дружина Бенеша відвідала Московський Художній Академічний Театр (спектакль «Російські люди»), а наступного дня президентська пара забажала подивитися у філії МХАТу спектакль «Піквікський клуб» (за Ч. Діккенсом) (Бенеш, 1945: 74). «Жіноча» складова частина візиту відобразилася і на тому, що на обід до Сталіна 28 березня (о 20 годині) офіційні особи були запрошені із дружинами. Форма одягу: для чоловіків - парадна 3 орденами, для жінок - вечірній туалет (довга сукня) (Бенеш, 1945: 90).

У квітні 1945 р. в Москві перебував маршал Й. Б. Тіто. Протокольним відділом НКЗС підготовано план зустрічі, перебування і проводів югославського лідера. На наступний день після прибуття Тіто відвідує В. Молотова, а потім Сталіна. Ввечері гості присутні в Большому театрі, в центральній ложі з радянського боку - В. Молотов, А. Вишинский та ін., до театру запрошено дипломатичний корпус. Центральна ложа прикрашена прапорами (Тіто, 1945: 119). Перед початком спектаклю звучать національні гімни Югославії та СРСР. На другий день перебування В. Молотов влаштовує на честь Тіто сніданок в особняку НКЗС на вулиці О. Толстого, 17. 12 квітня 1945 р. в ЦДЧА відбувся концерт. Перед початком концерту прозвучали югославський i радянський гімни. У першому відділі виконали «Кантату про Сталіна» (музика О. Александрова), «Поему про Україну» (музика О. Александрова), «Морську пісню» (музика О. Александрова), «Присмерк ночі впав на землю» (сербська пісня, обробка О. Александрова), «Вздовж по Пітерській» (обробка О. Александрова), «Степ та степ кругом» (обробка О. Александрова), «У лісі прифронтовому» (музика М. Блантера), «Червоноармійський танець». У другий відділ включили: хор із опери «Борис Годунов» М. Мусоргського, «Мрії» Р. Шумана, українські пісні Г. Давидовського, «Смуглянку» (музика А. Новикова), «Пісню Єрьомки» $з$ опери «Вража сила» О. Сєрова, англійську солдатську пісню, американську солдатську пісню, танець донських козаків (Тіто, 1945: 170). На концерті в перших рядах партеру перебували члени югославської делегації на чолі з Й. Б. Тіто, члени радянського уряду із дружинами.

У залі були присутні також вчені, письменники, артисти, деякі з них були запрошені з дружинами: академіки О. Греков, В. Обручев, Т. Лисенко, а також К. Сімонов, С. Маршак, В. Лебедєв-Кумач, I. Оренбург, С. Михалков, І. Москвін, Н. Хмельов, П. Садовський, А. Яблочкіна, О. Таїров, М. Охлопков, К. Завадський та ін. (Тіто, 1945: 156-159).

17 квітня делегація прибула до Києва, у супроводі Микити Хрущова відбувся огляд міста, а ввечері - обід на дачі Хрущова, наступного дня маршал Тіто наніс йому візит у Раднарком. До плану візиту були включені відвідування архітектурної виставки, театру, а 19 квітня в день вильоту гостям планували показати колгосп.

Наступний візит до СРСР урядової делегації Югославії на чолі 3 головою Ради міністрів, міністром народної оборони маршалом Й. Б. Тіто відбувся у травні 1946 р. Програма візиту включала в себе офіційні прийоми, гостям пропонували відвідати:

28 травня - Малий театр, спектакль «Пігмаліон»;

29 травня - М'ясокомбінат ім. Микояна, Театр Ленінського комсомолу (спектакль «Сірано де Бержерак»);

2 червня - футбольний матч на стадіоні «Динамо», Большой театр.

Список на прийом на честь приїзду маршала Тіто 30 травня 1946 р. із дружинами складався iз кількох частин. Спочатку члени уряду, потім МЗС СРСР (члени колегії, завідувачі відділами й управліннями, помічники міністра, замміністра і працівники секретаріатів, Протокольний відділ), ЦК ВКП (б), антифашистські комітети та інші офіційні служби (Тіто, 1946: 8-10).

Крім того, на прийомі були вчені (С. Вавилов, Н. Бруєвич та ін.), журналісти (редактори газет «Правда», «Известия», «Красная звезда», «Труд», 
«Новое время», «Красный флот»), письменники (В. Горбатов, Г. Мдіані, В. Іванов), артисти (В. Барсова, О. Лепешинська, С. Образцов, И. Моісеєв та ін. (на полях списку ремарка «були в Югославії»)), композитори (Д. Шостакович, Т. Хренніков, В. Мураделі, С. Прокоф'єв, А. Хачатурян та ін.), художники (І. Грабар, К. Юон, А. Пластов, О. Дейнека та ін.). Наприкінці списку вказувалися воєначальники (маршал Г. Жуков, адмірал флоту Н. Кузнєцов та ін.), члени шведської та ісландської торгових делегацій, голови дипломатичних представництв, акредитованих у Москві (всього 41), і технічна інтелігенція (Тіто, 1946: 12-18).

У 1946 р. найцікавішим із позиції організації та самого візиту стало відвідання СРСР делегацією членів Виконкому англійської Лейбористської партії М. Філіпе, Г. Клея та А. Бекона на чолі із професором Гарольдом Ласкі, в липні, через п'ять місяців після виголошення В. Черчиллем його знаменитої Фултонської промови. За три тижні до початку візиту деякі члени Лейбористської партії відвідали Москву у складі делегації керівників руху англо-радянської дружби. До складу делегації 3 дев'яти осіб входили і члени комуністичної партії Великої Британії. Гості побували в Москві, Ленінграді, Сталінграді, Києві, Вірменії, Грузії, Челябінську, Ризі (Ласки, 1946: 51).

Проїжджаючи Москвою, Ласкі пояснював Клею, що «після Жовтневої революції багато церков було зачинено і навіть зруйновано. Однак залишили всі ті церкви, які мають архітектурну чи історичну цінність» (Ласки, 1946: 18). Очевидно, професор Ласкі нічого не знав про вандалізм більшовиків у Кремлі, про знищення храму Христа Спасителя та інших пам'яток архітектури.

Побачивши газетну вітрину, Ласкі пояснив любов росіян до читання, поділившись своїми спостереженнями. «У Москві, - говорив він, - я бачив у 1934 р. чергу людей, що бажали купити книги Пушкіна, Толстого» (Ласки, 1946: 18). У Ленінграді гості відвідали голову міської ради П. Лазутіна, з яким бесідували про відбудову міста: англійців вразили руйнування Петергофу. Після огляду міста делегація подивилася виставу «Наталка Полтавка» Українського музичного драматичного театру ім. Т. Шевченка (Ласки, 1946: 27). Культурна програма була важливою складовою частиною візиту, але головна його мета - роз'яснення позиції Лейбористської партії в галузі внутрішньої та зовнішньої політики Великої Британії в бесідах із державними і партійними діячами (у бесідах із представниками громадськості гості старалися не торкатися питань політики).
3 особливою розкішшю святкувалося 21 грудня 1949 р. 70-річчя Сталіна, яке оголосили всенародним святом, і водночас воно стало приводом для демонстрації усьому світові досягнень СРСР. Серед закордонних правителів на ювілей був запрошений Голова Центрального народного уряду Китайської Народної Республіки Мао Цзедун, що прибув до Москви 16 грудня 1949 р. (Візит, 1949-1950: 42). Того самого дня його прийняв Сталін. На урочисте засідання у Большому театрі Мао Цзедуна запросили у президіум (Візит, 1949-1950: 1). До Большого театру отримали запрошення і голови посольств та місій іноземних держав, акредитованих у Москві.

Концертна програма в ніч із 21-го на 22 грудня складалася із трьох відділів. У першому виконувалися твори російської класики: М. Глінки (увертюри до опер «Руслан і Людмила» та «Іван Сусанін», танці з опери «Іван Сусанін» - полонез, вальс, мазурка, краков'як), О. Глазунова (концертний вальс), М. Мусоргського (полонез iз опери «Борис Годунов»), Римського-Корсакова (увертюра до опери «Царева наречена»), П. Чайковського (вальс, полонез із опери «Євгеній Онєгин», слов'янський марш, сюїта $з$ балету «Лускунчик»). У другому відділі прозвучали твори радянських композиторів: О. Александрова («Кантата про Сталіна»), І. Дунаєвського («Пісня про Батьківщину», «Концертний вальс», «Російська рапсодія», вальс до фільму «Моя любов», увертюра до оперети «Вільний вітер»), К. Лістова (обробка «Суліко»), Б. Мошкова (вальс «Весняна серенада»), Н. Ракова (Концертний вальс). Третій відділ склали твори західноєвропейських композиторів: Б. Сметани (мелодії з опери «Продана наречена»), Ф. Шопена (Полонез ор.40), Ш. Гуно (балетні сцени «Вальпургієва ніч» із опери «Фауст»), Й. Штрауса (вальси «На березі голубого Дунаю», «Казки віденського лісу»).

Концертна програма дозволяє судити про музичні смаки Сталіна. Якщо судити за кількістю авторських творів у концерті, то перевага надавалася творчості М. Глінки, П. Чайковського й I. Дунаєвського. Прикметно, що на концерті $з$ нагоди ювілею лідера багатонаціональної держави не представлені твори сучасних композиторів союзних республік, також не було спеціального відділу, присвяченого народній музиці, за винятком обробки К. Лістова грузинської пісні «Суліко».

Проте якщо репертуар урядових концертів вражав професійністю, то меню кремлівських прийомів - своїм цинізмом. Хоча більшість населення Радянського Союзу голодувало, у Кремлі на обіді у Сталіна на честь Мао Цзедуна 1 лютого 1950 p. 
подавали найвишуканіші делікатеси, які тільки можна було собі уявити, справжній Лукуллів бенкет. Головна мета сталінських прийомів - довести гостям, що СРСР розвивається успішно не тільки в економіці, але й у всіх напрямах культури та щоденного побуту.

На прийомі 14 лютого, влаштованому китайським послом, були присутні Сталін і його найближче урядове оточення, посли більшості соціалістичних держав. Академію наук СРСР представляли С. Вавилов, І. Бардін, В. Волгін, А. Торчієв. На прийомі були редактори газет і журналів («Правда», «Известия», «Новое время», «Литературная газета»); письменники (О. Фадєєв, К. Симонов, С. Михалков, А. Сурков, А. Сафронов, Л. Леонов, М. Аплетін, Б. Полевой, А. Первенцев, М. Бубеннов); архітектори (Н. Плотніков, В. Світличний); художники (Ф. Федоровський, Д. Налбандян, В. Єфанов, Г. Ряжський); музиканти (Т. Хрєнніков, Д. Кабалевский, Д. Шостакович, М. Голованов Р. Глієр, Д. Ойстрах, Л. Оборин); художні керівники театрів і артисти (К. Зубов, М. Кедров, Н. Охлопков, Е. Гоголева, О. Лепешинська, А. Тарасова, I. Козловский, I. Мойсеєв, Н. Казанцева, Г. Барінова, В. Марецька, А. Пирогов, М. Царев, Р. Симонов, М. Жаров, Н. Шпіллер); «робітники кіно» (С. Герасимов, Т. Макарова, Л. Варламов, Б. Андреєв, Л. Косматов, І. Пир'єв, М. Ладиніна, М. Чіаурелі, В. Пудовкін) (Візит, 1949-1950: 111-113). Запрошення на такі заходи представників мистецької й наукової інтелігенції означало передусім прихильність партійного керівництва і почесну позицію в радянській еліті.

За час перебування делегації в Москві 3 16 грудня 1949 до 17 лютого 1950 рр. для членів делегації - найближчого оточення Мао - організовано 19 екскурсій, а з 17 лютого до 19 березня для решти 18 учасників делегації - 8 екскурсій. Всього для членів китайської делегації організовано 27 екскурсій, у т. ч. мистецьких в Історичний музей, у Третьяковську галерею та ін. (Візит, 1949-1950: 3, 4). За цей період для членів делегації організовано перегляди 24 спектаклів, а саме: в Большому театрі («Червоний мак» Р. Глієра, «Князь Ігор» О. Бородіна, «Руслан і Людмила» М. Глінки, «Лебедине озеро» П. Чайковского, «Бахчисарайський фонтан» Б. Асаф'єва, «Кармен» Ж. Бізе); у МХАТі («Іван Грозний», «Анна Кареніна». «Глибока розвідка»); спектаклі в театрі оперети, в Театрі ім. К. Станіславського, вистави в Ляльковому театрі та цирку. Крім того, із 16 грудня 1949 до 19 березня 1950 рр. в «Зарядді» та в готелі «Москва» китайським гостям показали 23 кіножурнали та 46 кінокартин (Візит, 1949-1950: 5).
Смерть Сталіна багато змінила не лише у внутрішньому, але й у зовнішньому курсі СРСР. Ці зміни неминуче торкнулися і діяльності дипломатичних служб, у т. ч. й форм і змісту протоколів і програм зустрічі іноземних гостей. Вони стали, по-перше, дещо гнучкішими та враховували ширший спектр подій і місць перебування, по-друге, передбачали прийоми не лише «перших осіб», але і членів їхніх родин.

16 червня 1953 р. у Протокольному відділі МЗС СРСР відбулася зустріч із другим секретарем посольства Індії, на якій визначили програму перебування у СРСР дочки прем'єр-міністра Індії Джавахарлала Неру Індіри Ганді. 3 урахуванням побажань індійської сторони й особисто Індіри Ганді складено план візиту: у Москві планувалося із 26 червня до 1 липня і з 17 до 27 липня. Програма відрізнялася вже значно «гуманістичнішим» спрямуванням і навіть передбачала, окрім традиційного відвідування опер і драматичних вистав, Третьяковської галереї, Музею історії та реконструкції Москви, ще й візит до музею Толстого в Ясній Поляні та навіть духовної семінарії в Загорську (Візит, 1953: 10).

Період керівництва Микити Хрущова, названий в історії метафорою «хрущовської відлиги», позначився більш широким спектром також у дипломатичному протоколі. Варто проілюструвати цю епоху кількома яскравими прикладами. Із 29 квітня до 16 травня 1958 р. у СРСР на запрошення Президіуму Верховної Ради СРСР і Ради міністрів СРСР перебувала делегація Об'єднаної Арабської Республіки на чолі із президентом i головнокомандувачем Збройними силами ОАР Гамаль Абдель Насером. Делегація ОАР відвідала Ташкент, Баку, Сухумі, Сочі, Запоріжжя, Київ, Ленінград, Сталінград.

Аеродроми та вулиці міст, які відвідував Г. А. Насер, прикрашалися прапорами ОАР, СРСР і відповідної союзної республіки, вітальними транспарантами російською, арабською i мовою республіки, портретами Г. А. Насера. На аеродромах вивішувалися портрети Г. А. Насера та К. Ворошилова, а в Ташкенті - Г. А. Насера, К. Ворошилова та М. Хрущова (Візит, 1958: 176).

Протокольні заходи в Москві включали відвідини Мавзолея Леніна і Сталіна, Московського автомобільного заводу ім. І. Лихачова, університету, Большого театру (балет «Лебедине озеро» П. Чайковского), огляд міста.

Доказом зміцнення дружніх відносин між ОАР і СРСР може служити візит у 1963 р. (із 26 січня по 9 лютого) в Радянський Союз на запрошення дочки Голови Ради міністрів СРСР М. Хру- 
щова дочки президента ОАР Ходи Насер (Візит, 1963: 11). Її зустрічали в аеропорту Шереметьєво головний редактор газети «Известия» А. Аджубей із дружиною (дочкою М. Хрущова), головний редактор газети «Правда» Сатюков із дружиною i дочкою, заступник міністра закордонних справ СРСР С. Ларін і Г. Брежнєва. Х. Насер мешкала в державному особняку № 7 на Воробйовському шосе, 63 (Візит, 1963: 12). 27 січня Хода Насер відвідала Ніну Хрущову, за час перебування в Москві оглянула собори Кремля, побувала у Третьяковській галереї, університеті, Палаці піонерів, Домі моделей. У Большому театрі та Палаці з'їдів дивилася балети: «Лускунчик» і «Лебедине озеро» П. Чайковского, «Кам'яну квітку» С. Прокоф'єва, «Жизель» А. Адана.

Із 30 січня до 1 лютого Хода Насер перебувала у Ленінграді, де відвідала Ермітаж і Пушкіно, Палац шлюбів, познайомилася 3 молодятами студентами одного з ленінградських вишів. Вона була любителькою кіно, тому в Ленінграді подивилася радянські фільми «Подвиг Ленінграду», «Колеги», «Молодо-зелено», «Карнавальна ніч».

Якщо візит Г. А. Насера у 1958 р. продемонстрував зміцнення політичного авторитету Микити Хрущова, то візит до Радянського Союзу в 1963 р. дочки єгипетського лідера - це спроба вийти на новий рівень відносин.

У 1962 р. яскравою подією в політичному i культурному житті СРСР став приїзд до Москви королеви Бельгії Єлизавети. Особливість першого візиту європейського монарха в Радянський Союз полягала в тому, що королеву як почесну гостю II Міжнародного конкурсу ім. П. Чайковського запросили міністр культури К. Фурцева, голова Оргкомітету II Міжнародного конкурсу ім. П. Чайковського Д. Шостакович, голови журі конкурсу Д. Ойстрах, Е. Гілельс і М. Ростропович. Відомо, що всі бельгійські королі, починаючи 3 Леопольда I, надавали велике значення мистецтву як необхідній умові процвітання нації. Слизавета теж любила і добре зналася на мистецтві. 3 іменем королеви пов'язане проведення міжнародних конкурсів скрипалів (з 1973 р.) і піаністів (з 1938 р.) ім. Ежена Ізаї у Брюсселі, з 1951 р. у столиці Бельгії проводиться Міжнародний конкурс виконавців ім. королеви Слизавети.

Королева прибула до Москви 24 квітня на аеродром Шереметьєво, де іiі зустрічали: заступник голови Президіуму Верховної Ради Н. Органов, міністр культури К. Фурцева, заступник міністра закордонних справ С. Лапін, завідувач Протокольним відділом МЗС Ф. Молочков, Д. Шостакович, Д. Ойстрах, представники МЗС СРСР і Міністер- ства культури СРСР (Програма, 1962: 44). Аеродром прикрасили державними прапорами Бельгії та СРСР, але почесна варта не шикувалася, державні гімни не виконували. Королеву супроводжували до резиденції Н. Органов і К. Фурцева, іiі саму і ії почет розмістили в державному особняку на Ленінських горах із 24 до 27 квітня, в резиденції у Кремлі - із 28 квітня до 10 травня. Одразу після приїзду Слизавета забажала зустрітися з родиною Хрущових. Бесіда королеви з Микитою Хрущовим 30 квітня справила на неї сильне враження. Надзвичайний і повноважний посол короля Бельгії «у всіх країнах», особистий друг Єлизавети Едуард Ле Ге зазначив, що жоден державний діяч не приділяв так багато часу королеві, як М. Хрущов - майже 2 години. Перебуваючи в Москві, королева неодноразово висловлювала своє захоплення Хрущовим, називаючи його «найактивнішим і послідовним борцем за мир з усіх сьогоднішніх державних діячів» (Програма, 1962: 45).

На сніданку, який дала королева на честь К. Фурцевої та Н. Хрущової 26 квітня, Ле Ге сказав, що королева приїхала в Радянський Союз не лише слухати музику на Конкурсі ім. П. Чайковського, iї метою є також «подати приклад іншим державним діячам у встановленні дружніх відносин із СРСР». До слів, сказаних Ле Ге: «Бельгії потрібна така королева», вона додала: «А нам потрібний Хрущов» (Програма, 1962: 46). На бажання королеви вона двічі зустрічалася із професором Московської консерваторії Д. Ойстрахом, якого вона вважала «своїм першим радянським другом, що перекинув місток у встановленні музичних зв'язків між СРСР і Бельгією» (Програма, 1962: 46).

На Конкурсі ім. П. Чайковського $з$ першого дня Єлизавета висловила бажання переслухати радянських виконавців, додавши, що не пропускає жодного концерту радянських артистів у Брюсселі. Єлизавета дала високу оцінку конкурсу, назвавши його представницьким і таким, що перевершив iii очікування. Вона особливо відзначила гру В. Ашкеназі, Е. Вірсаладзе й О. Насєдкина. Деякі виконавці заходили в ложу королеви.

Поза конкурсом королева відвідала Дім-музей П. Чайковського у Клину і Загорськ, де оглянула Лавру і відвідала Духовну академію. Крім того, в Москві королева побувала в середній школі № 2 iз французькою мовою викладання, в Музичнопедагогічному інституті ім. Гнєсіних, на парфумерній фабриці «Нова зоря», ВДНГ, здійснила поїздку новими районами та вулицями Москви, прогулянку на «Ракеті» Каналом ім. Москви. Королева подивилася балети «Жизель» А. Адана 
та «Лускунчик» П. Чайковського, спектакль «Незвичайний концерт» у Центральному театрі ляльок і програму в Московському цирку.

Перед від'їздом королева Єлизавета висловила свою вдячність за теплий прийом і «за добре й цікаво складену програму іiі перебування в Москві» (Програма, 1962: 49). Ле Ге сказав перед від'їздом, що королева і він після повернення в Бельгію «подвоять свої зусилля в боротьбі за мир». На аеродромі Слизавета заявила, що в Бельгії вона розповість бельгійському уряду про гостинний прийом у Москві та про свої враження. 10 травня королева Бельгії Слизавета вилетіла на Батьківщину. Після повернення вона надіслала телеграму на ім'я М. Хрущова, Л. Брежнєва, К. Фурцевої, в яких дякувала за люб'язну гостинність радянського уряду і дружбу, проявлені до неї в Москві (Програма, 1962: 50).

Особливість офіційного візиту до СРСР президента Французької Республіки генерала Шарля де Голля із дружиною (20 червня - 1 липня 1966 р.) на запрошення Голови Верховної Ради й уряду СРСР полягала в тому, що після 1944 р. це був перший візит французького лідера у післявоєнні роки. Загалом програма візиту складена за схемою, тоді вже традиційною: візити, перемовини, обіди, прийоми; відвідання театру (Большой театр, балет С. Прокоф'єва «Ромео і Джульєтта»); покладення вінка до меморіальної дошки авіаполку «Нормандія - Неман». Президент відвідав Мосраду, університет ім. М. Ломоносова, Гвардійську Таманську дивізію ім. М. Калініна, побував на тактичних навчаннях мотострілкового батальйону, виступив на телебаченні (30 липня, запис зроблений у резиденції гостя у Кремлі) (Візит, 1966: 97). Для дружини президента підготували спеціальну програму: відвідування Кремля, Інституту педіатрії Академії медичних наук СРСР, чай «від Брежнєвої та Підгорної» (Візит, 1966: 98). У поїздках по країні де Голля супроводжував Підгорний (до Новосибірська) i Косигин (до Ленінграду, Києва, Волгограду).

Починаючи приблизно із середини 60-х рр., у матеріалах фонду Протокольного відділу здебільшого відсутня інформація щодо атмосфери, своєрідного «настрою» візиту. Необхідні відомості містять здебільшого неофіційні джерела листи, мемуари.

Так, у спогадах В. Суходрева містяться цікаві деталі візиту в СРСР прем'єр-міністра Канади П'єра Трюдо, з іменем якого пов'язаний період потепління і розвитку дружніх відносин двох країн. У 1971 р. Трюдо відвідав Радянський Союз. Він вражав всіх не лише стилем поведінки, але й своєю зовнішністю - ультрамодними широкими яскравими галстуками, піджаками 3 величезними лацканами, черевиками на платформі та розкльошеними штанами.

Можна сперечатися, наскільки такий зовнішній вигляд відповідає атмосфері офіційних прийомів, але очевидно, що він доречний на дискотеці, яку П. Трюдо разом із дружиною побажав відвідати в Києві. Прем'єр-міністр Канади не міг не поїхати в Україну, адже багато українців проживають у Канаді, і в деяких районах країни можуть вплинути на результати виборів.

Бажання П. Трюдо відвідати дискотеку чи нічний клуб без офіційного супроводу Суходрев передав начальнику охорони, який попросив 15-20 хвилин на підготовку. Дискотеку для прем'єр-міністра організували на Хрещатику, недалеко від резиденції, родина Трюдо пішла туди пішки (охорона була, але намагалася бути непомітною). «На Трюдо ніхто не звертав уваги. Нікому і в голову не могло прийти, що цей модно вдягнений піжон із бакенбардами, що обнімає худеньке довговолосе дівча (незадовго до візиту Трюдо одружився - О. 3., Л. К.) - прем'єр-міністр Канади» (Суходрєв, 1999: 224). У клубі Трюдо підвели до столика, накритому на двох. I почалася «шикарна імітація» життя нічного клубу: «гості» танцювали, світло пригасили. Трюдо із дружиною випили шампанське і «закружляли в танці». На думку Суходрева, який був на дискотеці, канадська пара танцювала «вельми хвацьки і запально» (Суходрєв, 1999: 224).

Візит Трюдо запам'ятався не тільки яскравими поїздками по країні. Були підписані важливі угоди, прийнята сумісна заява. Один із членів Політбюро запропонував навіть налагодити в СРСР виробництво тканин модних яскравих кольорів, але його поривання викликало очікувану реакцію: «Нi, нам цього не треба. Хай Трюдо сам такі галстуки носить...» (Суходрев, 1999: 231). В О. Косигіна 3 П. Трюдо після його візиту до СРСР налагодилися добрі стосунки, вони, за спостереженням В. Суходрева, із задоволенням спілкувалися один із одним.

Висновки. За, здавалося б, «сухою» мовою протоколу стоять конкретні особистості 3 неповторними характерами. В окремих випадках порушення протокольних норм не тільки не заважає вирішувати поставлені завдання, але й навіть сприяє їх втіленню. У більшості програм зарубіжних візитів до СРСР відвіданню України відводилося особливе місце, що особливо помітно в післявоєнні роки. Інтелектуальний потенціал України дозволяв республіці, незважаючи на Голодомор, репресії, втрати у Другій світовій війні, 
бути однією з найбільш розвинутих республік не тільки в економічному, але й у культурному сенсі.

Протягом століть дипломатичний протокол зазнав значних змін, незмінним залишалося одне - дипломатичні церемоніали, важливою складовою частиною яких була культурна, насамперед музичне мистецтво. Саме вони зобов'язані підтримувати ілюзію могутності держави. Вже на початку 20-х рр. стає очевидно, що неможливо вибудовувати партнерські відносини із зарубіж- ними країнами без дотримання загальноприйнятих європейських норм, традицій і умовностей у міжнародному спілкуванні. Нині триває процес демократизації протокольних норм. Поряд із цим 3МI, висвітлюючи закордонні візити глав держав і урядів, уважно відстежують стиль і манери поведінки представників політичної еліти. Дипломатичний протокол, будучи частиною державної церемоніальною культури, є ілюстрацією духовного, морального, політичного стану суспільства.

\section{СПИСОК ВИКОРИСТАНИХ ДЖЕРЕЛ}

1. Балканский. Речь. 1939. Киев. Архив внешней политики Российской Федерации (АВП РФ) Ф. 057. Оп. 19. П. 113. Д. 4. Л.8.

2. Бенеш. Программа пребывания. 1945. Москва. АВП РФ. Ф. 057. Оп. 25. П. 123. Д. 8. Л.76,74,90.

3. Борунков А. Ф. Дипломатический протокол в России. Москва, 2005. С. 150-163.

4. Визит Г. А. Насера. 1958. Москва. АВП РФ. Ф. 57. Оп. 44. П.243. Д. 45. Л.176.

5. Визит де Голля. 1966. Москва АВП РФ. Ф. 57. Оп. 63. П.500. Д. 43. Л.97,98.

6. Визит И. Ганди. 1953. Москва. АВП РФ. Ф. 57. Оп. 38. П.145. Д. 11. Л.10.

7. Визит Мао Цзедуна. 1949-1950. Москва. АВП РФ. Ф. 57. Оп. 34б. П.101. Д. 1. Л. 1,42,111-113.

8. Визит президента сената Данцига. 1929. Москва, Харьков. АВП РФ. Ф. 057. Оп. 9. П. 107. Д. 5. Л. 16, 17.

9. Визит У. Черчилля. 1944. Москва. АВП РФ. Ф. 057. Оп. 24. П.120. Д. 7. Л. 26.

10. Визит Х. Насер. 1963. Москва. АВП РФ. Ф. 57. Оп. 58. П. 425. Д. 32. Л. 11, 12.

11. Голубев А. В., Невежин В. А. Формирование образа Советской России в окружающем мире средствами культурной дипломатии, 1920-е - первая половина 1940-х гг. Москва, 2016. С. 232.

12. Де Голль. Программа пребывания. 1944. Москва. АВП РФ. Ф. 057. Оп. 24. П. 120. Д. 8. Л. 28, 48, 53, 54, 59.

13. Иден. Письмо в протокольный отдел. 1944. Москва. АВП РФ. Ф. 057. Оп. 24. П. 120. Д. 7. Л.5 0.

14. Ласки Г. Визит в Москву. 1946. Москва. АВП РФ. Ф. 057. Оп. 26. П.127. Д. 6. Л. 51, 18.

15. Лядов П. Ф. История российского протокола. Москва, 2004. С. 64-89.

16. Пребывание падишаха Афганистана в Москве. 1928. Москва. АВП РФ. Ф. 057. Оп. 8. П. 106. Д. 9. Л. 17.

17. Программа визита японской делегации. 1927. Москва. АВП РФ. Ф. 057. Оп. 6. П. 103. Д. 5. Л. 11.

18. Программа пребывания делегации Болгарии. 1939. Киев. АВП РФ Ф. 057. Оп. 19. П. 113. Д. 4. Л. 8, 10, 11, 14.

19. Программа пребывания кантонского минстра. 1925. Москва. АВП РФ. Ф. 057. Оп. 5. П.102. Д. 5. Л. 35, 36.

20. Программа пребывания королевы Бельгии Елизаветы. 1962. Москва. АВП РФ. Ф. 57. Оп. 57. П. 403. Д. 59. Л. $44-46,49,50$.

21. Пуанкаре. Телеграмма Эрио. 1922. Москва. АВП РФ. Ф. 057. Оп. 2. П. 101. Д. 1. Л. 19.

22. Суходрев В. М. Язык мой - друг мой. От Хрущева до Горбачева. Москва, 1999. С. 224, 231.

23. Тито И. Б. Визит в СССР в 1946 году. 1946. Москва. АВП РФ. Ф. 057. Оп. 26. П. 127. Д. 8. Л. $12,18$.

24. Тито И.Б. Программа пребывания. 1945. Москва. АВП РФ. Ф. 057. Оп. 25. П. 123. Д. 8. Л. 119, 170, 156-159.

25. Черчилль У. Вторая мировая война : в 6 т. Т. 6 : Триумф и трагедия. Москва : Военное издательство, 1955. C. 228,235 .

26. Чичерин Г. В. Письмо Фрунзе. 1925. Москва. АВП РФ. Ф. 057. Оп. 5. П. 102. Д. 5. Л. 1, 3.

\section{REFERENCES}

1. Balkanskiy. Rech [Speech]. 1939. Kiev. AVP RF F.057. Op. 19. P. 113. D. 4. L. 8. [in Russian].

2. Benesh. Programma prebyivaniya [Stay program]. Moscow. 1945. AVP RF. F. 057. Op. 25. P. 123. D. 8. L. 76, 74, 90. [in Russian].

3. Borunkov A.F. Diplomaticheskiy protkol v Rossii [Diplomatic protocol in Russia]. 2005. Moscow. [in Russian].

4. Vizit G. A. Nasera [G. A. Nasser's Visit]. 1958. Moscow. AVP RF. F.57. Op. 44. P. 243. D. 45. L. 176. [in Russian].

5. Vizit de Gollya [de Gaulle's visit]. Moscow. 1966. AVP RF. F. 57. Op. 63. P. 500. D. 43. L. 97, 98. [in Russian].

6. Vizit I. Gandi [I. Gandhi's visit]. Moscow. 1953. AVP RF. F. 57. Op. 38. P. 145. D. 11. L. 10. [in Russian].

7. Vizit Mao Tszeduna [Mao Zedong's visit]. Moscow. 1949-1950. AVP RF. F. 57. Op. 34b. P. 101. D. 1. L. 1, 42, 111-113. [in Russian].

8. Vizit prezidenta senata Dantsiga [Visit of Senate President Danzig]. Moscow, Harkov. 1929. AVP RF. F. 057. Op. 9. P. 107. D. 5. L. 16, 17. [in Russian].

9. Vizit U. Cherchillya [W. Churchill's visit]. Moscow. 1944. AVP RF. F.057. Op. 24. P. 120. D. 7. L. 26. [in Russian].

10. Vizit H. Naser [H. Nasser's visit]. Moscow. 1963. AVP RF. F. 57. Op. 58. P. 425. D. 32. L. 11, 12. [in Russian].

11. Golubev A. V., Nevezhin V. A. Formirovanie obraza Sovetskoi Rosii v okruzhayschem mire sredstvami kyltyrnoi diplomatii, 1920-e - pervaya polovina 1940-h gg. Formation of the image of Soviet Russia in the surrounding world by means of cultural diplomacy, 1920s - first half of the 1940s. S. 232. Moscow. 2006. [in Russian]

12. De Goll. Programma prebyivaniya [Stay program]. Moscow. 1944. AVP RF. F.057. Op. 24. P. 120. D. 8. L. 28, 48, 53, 54, 59. [in Russian]. 
13. Iden. Pismo v protkolnyiy otdel [A letter to the protocol department]. Moscow. 1944. AVP RF. F. 057. Op. 24. P. 120. D. 7. L.50. [in Russian]. sian].

14. Laski G. Vizit v Moskvu [Visit to Moscow]. Moscow. 1946. AVP RF. F.057. Op. 26. P.127. D. 6. L. 51, 18. [in Rus-

15. Lyadov P. F. Istoriya rossiyskogo protokola [History of the Russian Protocol]. Moscow. 2004 [in Russian].

16. Prebyivanie padishaha Afganistana v Moskve [Stay of the padishah of Afghanistan in Moscow]. Moscow. 1928. AVP RF. F.057. Op. 8. P. 106. D. 9. L. 17. [in Russian].

17. Programma vizita yaponskoy delegatsii [The program of the visit Japanese delegation]. Moscow. 1927. AVP RF. F. 057. Op. 6. P. 103. D. 5. L. 11. [in Russian].

18. Programma prebyivaniya delegatsii Bolgarii [The program of the stay the delegation of Bulgaria]. Kiev. 1939. AVP RF F. 057. Op. 19. P. 113. D. 4. L. 8, 10, 11, 14. [in Russian].

19. Programma prebyivaniya kantonskogo minstra [The program of stay the Kantom ministry]. Moscow. 1925. AVP RF. F. 057. Op. 5. P. 102. D. 5. L. 35, 36. [in Russian].

20. Programma prebyivaniya korolevyi Belgii Elizavetyi [The program of the stay Queen of Belgium Elizabeth]. Moscow. 1962. AVP RF. F. 57. Op. 57. P. 403. D. 59. L. 44-46, 49, 50. [in Russian].

21. Puankare Telegramma Erio [telegram to Erio]. Moscow. 1922. AVP RF. F.057. Op. 2. P. 101. D. 1. L. 19. [in Russian]. 22. Sukhodrev V. M. Yazyik moy - drug moy. Ot Hruscheva do Gorbacheva [My tongue is my friend. From Khrushchev to Gorbachev]. Moscow. 1999. P. 224, 231. [in Russian].

23. Tito I. B. Vizit v SSSR v 1946 godu [Visit to the USSR in 1946]. Moscow. 1946. AVP RF. F. 057. Op. 26. P. 127. D. 8. L. 12, 18. [in Russian].

24. Tito I. B. Programma prebyivaniya [Stay program]. Moscow. 1945. AVP RF. F.057. Op. 25. P. 123. D. 8. L. 119, 170, 156-159. [in Russian].

25. Churchill W. Vtoraya mirovaya voyna [World War II]. Moscow. 1955. P.P. 228-235. [in Russian].

26. Chicherin G. V. Pismo Frunze [Letter to Frounze]. Moscow. 1925. AVP RF. F. 057. Op. 5. P. 102. D. 5. L. 1, 3. [in Russian]. 